\title{
Szkice
}

\section{Muzeum narracyjne - muzeum doświadczeniowe. Uwagi terminologiczne}

Maria Kobielska

TEKSTY DRUGIE 2020, NR 4, S. 15-36

DOI: $10.18318 /$ td.2020.4.2 | ORCID: 0000-0003-4083-4061

$\mathbf{P}$ ojęcia „muzeum narracyjne” bez wątpienia najczęściej używa się do opisu i klasyfikacji nowych muzeów i wystaw historycznych, powstających w Polsce na przestrzeni ostatnich już ponad 15 lat, w ramach tzw. boomu muzealnego. Przeświadczenie o szczególnej roli narracji pojawia się także w komentarzach muzealników. Dla przykładu, w rozmowie dwojga dyrektorów ważnych krakowskich instytucji muzealnych, Zofii Gołubiew i Michała Niezabitowskiego, padło sformułowanie: „słowo narracja jest kluczem" - kluczem do atrakcyjności i wiarygodności współczesnego muzeum¹․ Konstrukcja określenia „muzea narracyjne” (w przeciwieństwie do bardziej na pierwszy rzut oka enigmatycznych ekwiwalentów, jak „nowe muzea”) zapowiada pewną teoretyczną konkretyzację, sugeruje wskazanie na określoną cechę interesującej grupy muzeów - narracyjność - która

1 ZZofią Gołubiew rozmawia Michał Niezabitowski, w: Muzea, muzealia, muzealnicy. Ważne rozmowy, red. P. Jaskanis, Muzeum Pałacu Króla Jana III w Wilanowie, Universitas, Warszawa-Kraków 2016, s. 25.
Tekst powstał w ramach projektu badawczego „Nowe polskie muzea historyczne" (numer rejestracyjny: 2018/31/D/ $\mathrm{HS} 2 / 03123)$, sfinansowanego ze środków Narodowego Centrum Nauki.
Maria Kobielska - dr, adiunktka w Katedrze Antropologii Literatury i Badań Kulturowych na Wydziale Polonistyki UJ, gdzie współtworzy też Ośrodek Badań nad Kulturami Pamięci. Kulturoznawczyni i literaturoznawczyni, zajmuje się współczesną polską kulturą pamięci. Opublikowała m.in. książkę Polska kultura pamięci WXXI wieku: dominanty. Zbrodnia katyńska, powstanie warszawskie istan wojenny (2016). Kontakt: maria.kobielska@uj.edu.pl. 
opisywałaby ich specyfikę. Z niemal hegemonicznej popularności tego terminu w dyskursie polskim - co, wyprzedzając, niekoniecznie odpowiada sytuacji na świecie - wynika zapewne fakt, że często pojawia się on raczej na zasadzie powszechnie zrozumiałego wskazania na pewną grupę muzeów, bez szerszego komentarza (czy problematyzacji) kwestii narracji. Określenie o takiej rozpoznawalności i uznaniu może funkcjonować więc dziś jako samooczywiste, również w tekstach stawiających gruntowne diagnozy stanu współczesnej polskiej kultury muzealnej.

Przykładem może być tekst Roberta Traby zamieszczony w publikacji podsumowującej I Kongres Muzealników Polskich. Badacz rozważa w nim pejzaż muzealny współczesnej Polski, kładąc nacisk na rolę „historycznych muzeów narracyjnych"2 w kształtowaniu społecznej pozycji muzeów i dyskursu na ich temat, a także na różne sposoby rozwiązywania przez nie problemów dotyczących formy ekspozycji, ich ideologicznej zawartości oraz demokratycznego potencjału muzeów. Formułuje również postulaty włączenia wieloperspektywicznego, dywersyfikującego i uwzględniającego kontrowersje sposobu myślenia do konstrukcji wystaw historycznych. Pojęcie „muzeum narracyjnego" nie potrzebuje w tym wywodzie problematyzacji - odnosi się jasno do interesującej autora grupy muzeów, reprezentowanej przez wymieniane przez niego „pięć największych historycznych muzeów narracyjnych"3 (Muzeum Powstania Warszawskiego, Muzeum Historii Polski - co ciekawe, w momencie pisania artykułu Traby, a także nadal pozostające w fazie przygotowań, Muzeum II Wojny Światowej, Muzeum Historii Żydów Polskich POLIN oraz Europejskie Centrum Solidarności). To, na czym w istocie polegałaby ich „narracyjność", pozostaje poza obszarem zainteresowania tekstu; pojęcie narracji pojawia się w nim niejako na bardziej ogólnym poziomie, uwzględniającym współczesną świadomość historyczną i pamięć zbiorową (mowa o „pustce narracyjnej w pamięci kulturowej Polski”" oraz, za Chantal Mouffe, o antagonistycznej, kosmopolitycznej i agonistycznej narracji historycznej).

Świeżym dowodem powszechności pojęcia muzeum narracyjnego jest wydana w znanej muzeologicznej serii Universitasu publikacja zbiorowa, stanowiąca - co istotne - efekt pracy zarówno badaczek i badaczy muzeów,

2 R. Traba Epoka muzeów? Muzeum jako medium, muzeum jako mediator, w: I Kongres Muzealników Polskich, red. Komitet Programowy I Kongresu Muzealników Polskich pod przew. M. Niezabitowskiego, red. prow. M. Wysocki, Narodowe Centrum Kultury, Warszawa 2015, s. 47.

3 Tamże, s. 48.

4 Tamże, s. 49. 
jak i muzealników i muzealniczek, eksponująca je w tytule: Muzeumizmiana. Losy muzeów narracyjnych ${ }^{5}$. W tomie tym podjęto próbę opisania genealogii muzeów narracyjnych, a także przedstawienia warunków, w jakich doszło do polskiego boomu, i jego przebiegu. Liczne studia przypadków poszczególnych muzeów mają różny charakter: spora część to niejako autokomentarze osób zaangażowanych w ich powstawanie (muzealników i projektantek), inne odnoszą się do badań różnych grup zwiedzających. W tekstach składających się na tom tytułowe pojęcie pojawia się ze zmienną, ale sporą częstotliwością, a niektóre komentarze dają pewien wgląd w sposób - a raczej sposoby - rozumienia go przez autorki i autorów. Co zaś szczególnie istotne w kontekście nazewnictwa, Dorota Folga-Januszewska i Paweł Kowal proponują w Muzeum izmianie definicję muzeum narracyjnego, wyeksponowaną przez wydzielenie w osobny, dwustronicowy rozdział książki.

Przy całej intuicyjności tego terminu nieoczywiste pozostają, jak sądzę, odpowiedzi na podstawowe pytania o jego zakres i znaczenie. Czy wszystkie współcześnie powstające muzea historyczne są muzeami narracyjnymi? Jeśli nie, jak można operacyjnie zdefiniować warunki, pod którymi dane muzeum jest narracyjne? Jeśli tak, na czym dokładnie polega szczególna narracyjność, którą należałoby w tej sytuacji uznać za dominantę współczesnych muzeów?6 A zatem, jak rozumiana jest narracja w odniesieniu do muzeów i czy tak powszechnie funkcjonujący termin został ugruntowany w badaniach, które pokazywałyby, dlaczego to narracyjność należy wysunąć na pierwszy plan w ich charakterystyce? Dążąc do odpowiedzi na te pytania, analizuję w tym tekście konkretne wystąpienia terminu „muzeum narracyjne” w dyskursie badań nad muzeami, zbieram płynące z nich intuicje, poszukuję genealogii

5 Muzeum izmiana. Losy muzeów narracyjnych, red. P. Kowal, K. Wolska-Pabian, Muzeum Powstania Warszawskiego, - Universitas, Warszawa-Kraków 2019.

6 Zasadne wydaje się pytanie, czy, ściśle rzecz ujmując, w tym kontekście powinna być mowa o muzeach, czy raczej o wystawach narracyjnych. Nie spotkałam się z przypadkiem, w którym określenie to byłoby wyraźnie odniesione nie tylko do konstrukcji wystawy, ale i do kształtu działalności całej instytucji. Badam jednak pojęcie zastane, będące w częstym użyciu, a niezależnie od tego jestem przekonana, że wystawy (zwłaszcza wystawy stałe) stanowią w wypadku interesującej mnie tu szczególnie grupy muzeów - czyli tych muzeów historycznych, które zostały otwarte w Polsce od 2004 roku albo które udostępniły w tym czasie nowe wystawy stałe - trzon ich tożsamości i funkcjonowania. Jeśli założenie to jest słuszne, pozwala wskazać na istotne przesunięcie w sposobie działania współczesnych muzeów historycznych, dla których wystawa jest istotniejsza niż kolekcja; muzea przede wszystkim wystawiają (a dalej - komunikują się ze zwiedzającymi, edukują ich etc.), a na dalszym planie gromadzą, przechowują, konserwują i badają obiekty tworzące kolekcję. 
terminu, rozważam pożytki, jakie płyną z jego stosowania, a także zastanawiam się nad możliwością alternatywnego podejścia do tego problemu.

\section{Muzeum narracyjne: sytuacja zastana}

W początkowej części tekstu potraktuję tom Muzeum i zmiana jako swego rodzaju reprezentatywną próbkę, zestawiając ze sobą sposoby użycia interesującego mnie pojęcia w kolejnych współtworzących go artykułach, wykorzystując ich liczbę i zróżnicowanie; uzupełniam jednak te obserwacje przykładami zaczerpniętymi z innych ważnych publikacji na temat polskiego boomu muzealnego.Zajmuję się w tym miejscu analizą dyskursu dotyczącego nowych polskich muzeów historycznych, nie zaś badaniem samych muzeów i ich wystaw i rozstrzyganiem, za pomocą jakich określeń najpełniej można by je opisywać, ale oczywiście ich przegląd stanowi tło mojego rozumowania. Zacznę więc od próby rekapitulacji „zastanej” sytuacji terminologicznej na polskim gruncie, starając się uporządkować pojawiające się sposoby rozumienia narracyjności muzeów.

Ponieważ terminu „muzeum narracyjne” często używa się jako samooczywistego, w wielu wypadkach jego wykorzystanie nie będzie pociągać za sobą definicji - dorozumiana jest wspólnota komunikacyjna dotycząca identyfikacji obiektów, które można zaliczyć do tej klasy. Wydaje się, że wspólnota ta często opiera się na niewysłowionej definicji prototypowej: przez muzea narracyjne rozumiane są muzea postrzegane jako podobne do prekursorskiego w Polsce Muzeum Powstania Warszawskiego, a poprzez nie - do pewnego zachodniego wzorca. I tak np. w tekście Jana Ołdakowskiego ze wspomnianego tomu odpowiedź na tytułowe pytanie, sformułowane ogólnie i dotyczące przyczyn powstawania „muzeów historycznych narracyjnych"7, została oparta w całości na uogólnionych doświadczeniach MPW (jest to oczywiście więcej niż zrozumiałe ze względu na osobę autora, jednego z twórców tego muzeum - ale zarazem znamienne). Podjęcie tego „prototypowego" sposobu myślenia znajduje potwierdzenie w tekście dyrektora innego muzeum, Roberta Kostry (Muzeum Historii Polski), który kładzie nacisk na to, że MPW „zaadaptowało do polskich warunków, a nawet twórczo wzbogaciło rozwiniętą dekadę wcześniej na Zachodzie koncepcję narracyjnego muzeum historycznego"8. Wreszcie ta domyślna, dotąd niewypowiedziana

7 J. Ołdakowski Dlaczego powstajq muzea historyczne narracyjne, w: Muzeum izmiana..., s. 73.

8 R. Kostro Doświadczenie Muzeum Historii Polski, w: Muzeum i zmiana..., s. 125. 
definicja pojawia się wprost w opublikowanym w Muzeum i zmianie raporcie dotyczącym oddziaływania muzeów na ich miejskie otoczenie, przygotowanym nie przez specjalistów z branży muzealnej, lecz przez międzynarodową firmę PwC, zajmującą się doradztwem i audytami. Jego autorzy rzeczowo deklarują: „Skupiliśmy się na nowoczesnych muzeach narracji historycznej, czyli instytucjach o podobnych charakterystykach i tematyce, jak Muzeum Powstania Warszawskiego"?.

Częsta - niekiedy w tych samych pracach - jest też sytuacja, gdy użycie pojęcia "muzeum narracyjne" pociąga za sobą pewną próbę dodefiniowania, jednak, też ze względu na inne priorytety badawcze, próby te mają charakter powierzchowny, a czasem nawet proponują definicję typu idem per idem, odwołując się ponownie do pojęcia narracji lub „opowieści”. I tak muzeum narracyjne jest objaśniane jako „nowoczesne muzeum opowiadające"10, „opowiadające historię"11, "opowiadające najnowszą historię"12 czy też charakteryzujące się „narracyjną strukturą ekspozycji”"13. W raporcie $\mathrm{PwC}$ znalazła się podobnie skonstruowana wzmianka o tym, że sformułowanie „muzea narracji historycznej” oznacza takie, które „opisują pewien wycinek historii i wokół niego budują swoją ekspozycję i działalność"14 - co z kolei odnosić się może do każdego muzeum historycznego. Niekiedy też „narracja muzealna" pojawia się nie tyle w odniesieniu do charakterystyki samej wystawy, ile sposobu interpretacji wydarzeń historycznych - rozumiana jest więc jako przekaz czy przesłanie, punkt widzenia ${ }^{15}$. Nazwa „muzeum

9 M. Walewski, A. Wudarczyk Rola nowoczesnych muzeów narracyjnych w rozwoju miast, w: Muzeum izmiana..., s. 268.

10 I. Kąkolewski Co decyduje i będzie decydować o atrakcyjności przekazu w muzeum historycznym? Kilka refleksji i proroctw, a może tylko utopistycznych marzeń, w: Historia Polski od-nowa. Nowe narracje historii i muzealne reprezentacje przeszłości, red. R. Kostro, K. Wóycicki, M. Wysocki, Muzeum Historii Polski, Warszawa 2014, s. 108.

11 K. Wolska-Pabian Nowe zadania muzeów narracyjnych na przykładzie Muzeum Powstania Warszawskiego, w: Muzeum i zmiana..., s. 91.

12 B. Kerski Europejskie Muzeum Solidarności (ECS) w Gdańsku. Muzeum Solidarności w połączeniu z instytucją wspierająca kulturę obywatelskq, w: Muzeum i zmiana..., s. 120.

R. Kostro Doświadczenie..., s. 126.

M. Walewski, A. Wudarczyk Rola nowoczesnych muzeów..., s. 272.

15 Por. np. G. Zubrzycki Między historiq̨, pamięciq̨ wspólnq̨ i mitologią narodową: wyzwania i szanse współczesnych muzeów, w: Historia Polski od-nowa, s. 21 - mowa o „zmianie narracji historycznej Muzeum Oświęcimia-Brzezinki” i następującym „szoku narracyjnym” u części Polaków. 
narracyjnego" dla „muzeum proponującego pewną wizję przeszłości” byłaby jednak oczywiście zbędna - wizję taką proponuje każde muzeum, a już na pewno muzeum historyczne.

Gdy pojawia się próba doprecyzowania terminu, często jako kluczowe wskazywane są takie aspekty „muzeów narracyjnych”, które nie łączą się wprost z narracyjnością. Są to więc ujęcia, które dookreślają pewne wspólne cechy interesujących mnie muzeów, jednak nie uzasadniają przyjmowanej dla nich nazwy; wskazywane w nich charakterystyki współczesnych muzeów historycznych mogą być przy tym jak najbardziej trafne.

I tak szczególnie często jako pierwsza cecha charakterystyczna „muzeów narracyjnych" pojawia się emocjonalność ich przekazu i oddziaływania. Piotr Kosiewski pisze we wspomnianym tomie o "szczególnej roli emocji”, których „wywoływaniu [...] jest podporządkowana cała narracja” ${ }^{\text {, }}$, zaś Jan Ołdakowski o tym, że „zadaniem historycznego muzeum narracyjnego jest wyrobienie u ludzi emocjonalnego stosunku do przeszłości, tak by wiedza i emocje szły w parze"17. W innym miejscu Monika Heinemann, niemiecka historyczka i znawczyni polskich muzeów, wskazuje na emocjonalność jako na definicyjną cechę muzeum narracyjnego, powołując się na kanadyjską muzeolożkę Robin Ostow, która „definiuje ten typ instytucji jako ukierunkowany tak na intelektualne, jak i emocjonalne zaangażowanie zwiedzającego - widz ma włączyć się w przedstawiane wydarzenia jako ich uczestnik"18. Kwestia zaangażowania pojawia się także na ogólniejszym poziomie: kluczowym efektem działalności takiej instytucji ma być stworzenie i zaktywizowanie społeczności wokół muzeum ${ }^{19}$.

Muzeum narracyjne tłumaczy się więc jako muzeum emocjonalne i angażujące, co dalej łączy się z interaktywnością - najpierw rozumianą na ogólnym poziomie jako szczególna sytuacja komunikacyjna, odmienna od prostego nadawczo-odbiorczego schematu tradycyjnego muzeum. Piotr Majewski ujmuje to w następujący sposób: pojęcie „muzeum narracyjne” ma oznaczać „instytucję nastawioną na przekazywanie wiedzy, włączenie w proces jej konstruowania publiczności muzealnej, dopuszczającą możliwość wchodzenia

16 P. Kosiewski Muzeum i narracja. Kilka uwag, w: Muzeum i zmiana..., s. 65.

17 J. Ołdakowski Dlaczego..., s. 77.

18 M. Heinemann Między Wschodem a Zachodem: pytanie o specyfikę narracji muzealnej w Europie Środkowej i Wschodniej, w: Historia Polski od-nowa..., s. 47.

19 J. Ołdakowski Dlaczego..., s. 77. 
w interakcje z muzealiami"20 . Interakcja zwiedzających z elementami wystawy - którą trzeba rozumieć w kategoriach ich decyzji, wyboru, manipulacji i sprawczości - pojawia się w niemal każdej próbie doprecyzowania cech muzeów narracyjnych ${ }^{21}$.

Muzea narracyjne są również opisywane w kategoriach odnoszących się do technik wystawienniczych - sposobów urządzenia narracyjnych ekspozycji. Pojawia się tu często wskazanie na użycie multimediów (choć jest to zarazem ten element, z którego „obowiązkowością" w wystawie narracyjnej badacze najczęściej polemizują) ${ }^{22}$.To, czym wyróżniają się muzea narracyjne, może zostać określone np. jako „atrakcyjna warstwa plastyczna”, „rozbudowana scenografia" ${ }^{23}$, budowanie ekspozycji z różnego rodzaju elementów (tekstowych, wizualnych, dźwiękowych, w tym projekcji, stanowisk komputerowych itd.), oddziaływanie na wzrok i słuch, ale także dotyk i zmysł równowagi. Jak pisze Igor Kąkolewski, ,istotą i szansą ekspozycji narracyjnej jest «poszerzenie kontaktu» z widzem na poziomie nie tylko odbioru wizualnego, lecz także innych zmysłów"24. Słowami-kluczami wydają się w tym wypadku atrakcyjność, różnorodność i wielozmysłowość. Cytowany badacz dalej opisuje udane muzeum narracyjne przez podobieństwo do medium teatru, jako „teatr czterech zmysłów”25.

Każde z tych podejść przynosi konkretne obserwacje, pozwalające na rozpoznanie pewnych cech powtarzających się w grupie współczesnych muzeów historycznych. Żadne nie stanowi jednak mocnego uzasadnienia dla określenia jej akurat mianem „muzeów narracyjnych”: emocjonalność, interaktywność, zaangażowanie, multimedialność, atrakcyjność, różnorodność i wielozmysłowość są terminami z innego porządku niż narracja i nie są inherentnie związane z narracyjnością. (Wydaje się, że jakkolwiek rozumieć „muzeum narracyjne”, trudno uznać znaczeniową tożsamość narracji i różnorodności,

P. Majewski Narracja, inaczej - kilka słów o Historii, muzeach i tych, którzy je odwiedzają, w: Muzeum i zmiana..., s. 53-54.

Por. np. w tomie Muzeum i zmiana...: B. Kerski Europejskie Centrum Solidarności, s. 120, B. Sajduk Pokolenie Z w przestrzeni muzeum narracyjnego, s. 210-211, R. Kostro Doświadczenie..., s. 125.

Por. np. P. Kosiewski Muzeum i narracja..., s. 61-62.

R. Kostro Doświadczenie..., s. 125.

I. Kąkolewski Co decyduje..., s. 109.

Tamże, s. 110. Kąkolewski ma na myśli wzrok, słuch, dotyk i węch. Metafory i porównania teatralne pojawiają się w stosunkowo licznych spośród analizowanych tekstów. 
wielozmysłowości czy interaktywności; trzeba przyjąć możliwość istnienia muzeum nienarracyjnego, które będzie różnorodne, wielozmysłowe czy interaktywne). Tym bardziej dotyczy to powtarzającego się i ogólnikowego określania „muzeów narracyjnych” jako nowych bądź nowoczesnych - na ogół przez skontrastowanie z równie intuicyjnie rozumianym tradycyjnym muzeum, z którego "naturalnych ograniczen" ${ }^{26}$ te pierwsze się wyzwalają ${ }^{27}$. W cytowanej na początku rozmowie Michała Niezabitowskiego z Zofią Gołubiew narracja zostaje skojarzona $\mathrm{z}$,nowym, atrakcyjniejszym językiem”28, odpowiadającym współczesności. Wymieniane tu przez rozmówców różne również niehistoryczne - wystawy ${ }^{29}$, które określają jako narracyjne, charakteryzują się „wspaniałymi pomysłami”, „twórczymi wizjami”, „tworzeniem napięć"30. Kluczem do narracyjności okazywałaby się kreatywność kuratora i dobry, wyrazisty pomysł dotyczący sposobu prezentacji tematu - byłoby to więc określenie wartościujące.

Niemal wszystkie opisane tu strategie zostały zastosowane przez Dorotę Folgę-Januszewską i Pawła Kowala w zaproponowanej przez nich wspomnianej definicji muzeum narracyjnego. Przytaczam ją w całości:

Współczesne muzeum narracyjne związane jest ze zmianami w muzealnictwie światowym, jakie zaszły na przełomie ostatniej dekady XX wieku i początku XXI stulecia. Do zadań muzeum narracyjnego należą nie tylko zbieranie, konserwacja i przechowywanie oraz prezentowanie i promowanie informacji o zbiorach. Inicjatorzy, formalni organizatorzy danej instytucji kultury lub/i realizatorzy ekspozycji wykazują ambicję opowiedzenia przy pomocy ekspozycji jakiejś wyodrębnionej historii.

Tamże, s. 108.

O „nowoczesnym muzeum" szeroko piszą też autorzy wspomnianego raportu PwC, mając na myśli techniki wystawiennicze, narzędzia marketingowe oraz działanie w ramach rynku. Por. M. Walewski, A. Wudarczyk Rola nowoczesnych muzeów..., s. 269-271. Z utożsamieniem muzeum narracyjnego i nowoczesnego dyskutuje natomiast Piotr Kosiewski (Muzeum i narracja, s. 60 in).

\section{ZZofiq Gołubiew rozmawia Michał Niezabitowski, s. 25.}

Wymieniana jest wystawa stała w Fabryce „Emalia” Oskara Schindlera (Muzeum Krakowa) oraz wystawy czasowe Muzeum Narodowego w Krakowie: słynny Polaków portret własny z 1979 roku (kurator: Marek Rostworowski), wystawa twórczości Tadeusza Kantora z 1991 roku (kuratorzy: Gołubiew, Jan Kolanowski) oraz Stanisława Wyspiańskiego teatr ogromny z 2007 (Janusz Wałek). 
Jej celem jest nie tylko prowadzenie narracji, ale też zaproszenie do dyskusji na temat prezentowanego wydarzenia czy zjawiska. W związku z tym rozszerza się zasób metod eksponowania przedmiotów z zastosowaniem zarówno tradycyjnych (na przykład scenografia), jak i nowoczesnych technik prezentacji, w tym wirtualizacji przekazu. Twórcy ekspozycji narracyjnej odwołują się jednocześnie do poznawania poprzez zmysły (wzrok, dotyk, dźwięk, zapach), ale także przywiązują wagę do roli emocji w odbiorze. Koncentracja tych celów, metod i bodźców, oraz intencje twórców, by stworzyć wielowątkową narrację, pozwalają mówić o narracyjności muzeum. ${ }^{31}$

Autorzy tej definicji kontrastują działalność muzeum narracyjnego z tradycyjnymi zadaniami muzeów jako takich (koncentrujących się na kolekcjach) i wskazują na nie jako na zjawisko ściśle historyczne, związane ze współczesnością. Charakterystyka takiego muzeum zostaje mocno skojarzona z niekoniecznie narracyjnymi cechami ekspozycji: angażowaniem zwiedzających, emocjonalnością i szczególnymi technikami wystawienniczymi (różnorodność, interakcyjność, multimedialność, wielozmysłowość). Narracyjność muzeum polega na „opowiadaniu wyodrębnionej historii”, ,tworzeniu wielowątkowej narracji" - autorzy pozostają więc na poziomie sporej ogólności, z tym że kładą nacisk na "narracyjne” intencje bądź ambicje twórców muzeum. Miałyby one mieć decydujący wpływ na zakwalifikowanie danego muzeum jako narracyjnego, co oczywiście nie może być satysfakcjonujące, jeśli chcemy potraktować narracyjność jako kategorię analityczną. Definicja ta jest natomiast reprezentatywna dla tego, w jaki sposób pojęcie muzeum narracyjnego jest najczęściej wyjaśniane i używane w tekstach badaczy polskiego boomu muzealnego.

Ten enumeracyjny opis jest zaprojektowany w taki sposób, aby odbijało się w nim każde współczesne muzeum historyczne. $Z$ analitycznego punktu widzenia mamy do czynienia z listą cech pochodzących z różnych porządków, co sugeruje, że "muzeum narracyjne” charakteryzuje się wieloma z nich, ale zapewne niekoniecznie wszystkimi. Jeśli natomiast chodzi o sposób ujęcia samej narracyjności - „opowiedzenia jakiejś historii” - jest on tu na tyle ogólny, że można by zasadnie zastanawiać się, czy nie dotyczy to każdego muzeum w ogóle, nie tylko historycznego i nie tylko współczesnego. Dorota Folga-Januszewska w tekście otwierającym Muzeum i zmianę pokazuje 
„historię związków muzeów i narracji”32 obejmującą również te dawne i najdawniejsze muzea. Do podobnych wniosków skłaniają rozważania Anny Ziębińskiej-Witek, która zwraca uwagę na bardzo szerokie rozumienie narracji w metodologii historii: za wystawę narracyjną można uznać właściwie każdą integrację obiektów prezentującą wynik badań historycznych w jakimś porządku. W tym sensie o narracyjności jako o pewnej ramie można mówić w wypadku niemal każdej wystawy, a właściwie także kolekcji stanowiącej pewną całośśc ${ }^{33}$. W innym miejscu badaczka podkreśla narracyjną strukturę najbardziej tradycyjnych wystaw historycznych, w tym sensie, że charakteryzują się one linearnością, chronologią i klasycznym układem fabularnym, "gdzie akcja ma swój początek, rozwinięcie i zakończenie" ${ }^{34}$. Tak rozumiana narracyjność nie może być operacyjnym pojęciem pozwalającym na wyodrębnienie specyfiki współczesnych muzeów ${ }^{35}$.

\section{Muzeum narracyjne czy narracja w muzeum?}

W tej sytuacji zastanowię się nad takimi poglądami dotyczącymi narracyjności muzeów, które pozwalałyby w bardziej specyficzny sposób odpowiedzieć na pytanie, na czym miałaby ona polegać - zwłaszcza w odniesieniu

każda ekspozycja muzealna może być potraktowana jako narracyjna. Z drugiej [strony - przyp. M.K.] - mamy jednak do czynienia z wyjątkowym zjawiskiem powszechnej narracji w muzeach historycznych naszych czasów. Na początku XX wieku nastąpił w Polsce wzrost zainteresowania muzealnictwem historycznym o charakterze narracyjnym [...]" (Społeczny, cywilizacyjny i polityczny kontekst polskiego boomu muzealnego, w: Muzeum i zmiana..., s. 31). Z kolei Barbara Kirshenblatt-Gimblett dostarcza użytecznego kontrprzykładu, pisząc o otwartym na nowo w 2017 roku Muzeum Warszawy, którego nowa wystawa stała Rzeczy warszawskie opiera się na kolekcji i prezentuje w tematycznych gabinetach tysiące pochodzących z niej obiektów: "Jako całość Muzeum Warszawy opowiada historię, czy raczej wiele historii, nie jest jednak muzeum narracyjnym" (Inscenizowanie historii. Muzeum Historii Żydów Polskich Polin, przeł. M. Gugała, w: Muzeum i zmiana..., s. 102). Więcej o Muzeum Warszawy - por. J. Wawrzyniak, Ł. Bukowiecki Portretowanie miasta w Muzeum Warszawy. "Rzeczy warszawskie” wobec modelu muzeum narracyjnego, w tym numerze „Tekstów Drugich”. 
do konstrukcji wystaw. Rozpocznę od narzucającej się kwestii, którą dotąd pozostawiałam na boku: wcześniejszego zagranicznego wzorca muzeum narracyjnego, o którego istnieniu piszą wyraźnie niektórzy cytowani dotąd badacze - jak Kostro, wskazujący wprost, jak wspominałam, że polskie muzea wykorzystują „rozwiniętą dekadę wcześniej na Zachodzie koncepcję

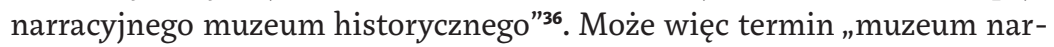
racyjne" stanowi po prostu przeniesienie pojęcia funkcjonującego w innym obiegu naukowym, gdzie wszystkie nasuwające się pytania zostały już rozważone?

Sprawa wydaje się jednak bardziej skomplikowana. Z pewnością polski boom muzealny został poprzedzony - i zainspirowany - przez liczne instytucje działające przede wszystkim w krajach Europy Zachodniej i w świecie anglosaskim, wcielające szczególny pomysł na muzeum, charakteryzujący się wymienionymi wyżej cechami. Krótko rzecz ujmując - łączność między polskimi i zagranicznymi tendencjami wystawienniczymi w zakresie muzeów historycznych jest niewątpliwa. Wydaje się jednak, że światowe museum studies niekoniecznie dostarczają aż tak mocnego zaplecza dla rozpowszechnionego w Polsce terminu, jak można by się spodziewać. Określenia narrative museum oczywiście pojawia się na tym obszarze, jednak nie w tak jednoznacznie hegemoniczny sposób; sygnalizować może to fakt, że nie figuruje ono np. w tytułach najważniejszych serii wydawniczych i monografii, w których zgłębiane są zagadnienia współczesnego muzealnictwa. Częściej mowa opisowo o różnych postaciach narracji w muzeach czy na wystawach, ich relacjach z narracjami historycznymi, a zwłaszcza narodowymi, niż konkretnie o „muzeum narracyjnym".

Łatwo w tej sytuacji zidentyfikować najbardziej wpływowe źródło tego pojęcia: to autokomentarz twórców United States Holocaust Memorial Museum w Waszyngtonie (otwartego w 1993 roku), wydany w postaci książkowej w $1995 \mathrm{roku}^{37}$. Publikacja ta, obszerna i obficie ilustrowana fotografiami, łączy role pamiątki, katalogu, przewodnika po budynku, wystawie stałej i innych działaniach USHMM ze szczegółową relacją z procesu powstawania muzeum - jest przeznaczona również „dla muzealników chcących zapoznać się z metodami i strategiami projektanckimi, które pozwoliły abstrakcyjne marzenie o tym niezwykłym muzeum przekształcić w trójwymiarową

36 R. Kostro Doświadczenie..., S. 125.

37 J. Weinberg, R. Elieli The Holocaust Museum in Washington, Rizzoli International Publications in collaboration with The United States Holocaust Memorial Museum, New York 1995. 
rzeczywistość"38. Pierwszy podrozdział części dotyczącej wystawy został zatytułowany A narrative museum i jest poświęcony mocnemu wyłożeniu pryncypiów narracyjnej koncepcji wystawienniczej Jeshajahu Weinberga ${ }^{39}$.

Charakterystyka muzeum narracyjnego jest tu zbudowana na mocnym odróżnieniu od „większości muzeów historycznych”. Podstawą funkcjonowania tych ostatnich jest „kolekcja dzieł sztuki i artefaktów odnoszących się do historii" ${ }^{40}$, których autentyczność odgrywa kluczową rolę. Muzeom tym autorzy przyznają istotną rolę wiedzotwórczą, ale odmawiają potencjału edukacyjnego rozumianego jako oddziaływanie na zwiedzających w taki sposób, aby „zmieniali się oni i rozwijali umysłowo, emocjonalnie i moralnie"41. Ten potencjał staje się kluczowym elementem tożsamości muzeum narracyjnego i jest podkreślany wielokrotnie w toku wywodu.

Odzwierciedlone zostały tu precyzyjnie intuicje i zasady USHMM, których echa pobrzmiewają w wielu wystawach historycznych czerpiących z niego inspiracje. Skupię się jednak w tym miejscu przede wszystkim na wyłaniającym się z tekstu sposobie rozumienia narracyjności. Po pierwsze, chodzi tu o budowanie ciągłości, spójności i kontekstowości wystawy. „Ciągłość narracji jest tak samo ważna, jak same obiekty [na wystawie - przyp. M.K.]”, które stają się elementami budującymi „linię fabularną". Oznacza to zarazem, że zostają umieszczone w konkretnych kontekstach znaczeniowych, a ich funkcją jest wyrażanie szerszych, nadbudowujących się nad tymi układami sensów. Zwiedzający, „wciągnięci w bieg narracji, postrzegają wystawę przez pryzmat [następujących po sobie - przyp. M.K.] sekwencji, koherencji i transformacji" ${ }^{22}$ - są więc nastawieni przede wszystkim na scalanie percypowanych elementów w kompleksową narrację oraz jej rozwój w czasie. Po

38 Tamże, s. 49 [przeł. M.K.].

39 Jak podkreślają autorzy tej prezentacji, koncepcja ta została pioniersko wypróbowana przez telawiwskie Muzeum Żydowskiej Diaspory (obecnie: Muzeum Narodu Żydowskiego Bet ha-Tefucot), założone w 1978 roku, którego pierwszym dyrektorem był Weinberg przed rozpoczęciem swojej misji w USHMM.

40 J. Weinberg, R. Elieli The Holocaust Museum..., s. 49 [przeł. M.K.]. Za cytowanymi wyżej uwagami Anny Ziębińskiej-Witek można by w tym miejscu zauważyć, że każda kolekcja może być potraktowana jako narracja, co widać szczególnie przez pryzmat ewentualnych zakłóceń (sama możliwość zauważenia urwania, niepełności, przypadkowości czy reorganizacji kolekcji w tym ujęciu potwierdza jej narracyjny charakter - gdyby kolekcja była tylko zbiorem elementów, nie byłoby to w ogóle możliwe). A. Ziębińska-Witek Historia w muzeach..., s. 69. 
drugie, narracja jest tu postrzegana jako narzędzie identyfikacji z bohaterami opowieści. Sprawia, że odbiorca (zwiedzający) skupia się na biegu wydarzeń (czy wręcz jest przez niego pochłonięty), „rzutuje” siebie samego w fabułę i musi odnieść się do znaczeń, jakie z niej wynikają. Na tym polega emocjonalne (i w efekcie edukacyjne) oddziaływanie muzealnej narracji.

W konsekwencji kluczowe z perspektywy organizacji wystawy różnice między muzeum opartym na kolekcji a tym narracyjnym to, po pierwsze, niezmienność wystawy stałej (ze względu na zintegrowanie wszystkich jej elementów ich przestawianie czy zmiana aranżacji oznaczałyby modyfikację narracji, a ponadto wymagałyby pokrycia kosztów przebudowy), po drugie, kluczową rolę historyka (a nie kuratora) w powstawaniu wystawy, po trzecie, z góry określoną ścieżkę zwiedzania (odpowiadającą fabule [story line]), po czwarte, nieużyteczność tradycyjnego katalogu, rozumianego jako lista wystawianych obiektów wraz z opisami, dla oddania struktury i sensu wystawy narracyjnej $j^{43}$. Ten instruktywny wywód jest jednocześnie wyrazem przywiązania do - tym razem - bardzo konkretnego rodzaju narracji. Jak komentuje Stephan Jaeger w swojej niedawnej książce o współczesnych muzeach poświęconych II wojnie światowej, Weinberg docenia przede wszystkim użyteczność narracji linearnej, podążającej w konkretnym kierunku (progressive), oraz dąży do ramowania, „połączenia wielu głosów w jedną większą opowieść" czy nawet „wielką narrację" ${ }^{44}$. Wypełniając treścią określenie "muzeum narracyjne”, twórcy USHMM idą więc w kierunku, który można sobie wyobrazić jako jeden z wielu możliwych, zwłaszcza jeśli zainspirować się różnorodnością form narracji pokazywaną i problematyzowaną przez badania współczesnej literatury i kultury.

Do precedensowej myśli Weinberga odwołuje się Barbara Kirshenblatt-Gimblett w swoich komentarzach dotyczących koncepcji wystawy stałej w Muzeum POLIN, za którą ta badaczka odpowiadała jako główna kuratorka. W wywodzie Kirshenblatt-Gimblett mającym na celu odróżnienie muzeów narracyjnych od nienarracyjnych wyróżniłabym dwa elementy. Pierwszym z nich jest ustanowienie opowieści, prowadzonej w ramach „multimedialnej wystawy narracyjnej" ${ }^{45}$, na szczycie hierarchii ważności muzeum, wyznaczającej sposoby podejmowania decyzji - jest ona „sercem" i „punktem wyjścia”

43 Tamże, s. 51.

44 S. Jaeger The Second World War in the Twenty-First-Century Museum. From Narrative, Memory, and Experience to Experientiality, Walter de Gruyter, Berlin-Boston 2020, s. 22 [przeł. M.K.]. 
działalności muzeum. Potrzeby opowieści przeważają więc nad różnego rodzaju ograniczeniami, np. wynikającymi z kształtu i sytuacji kolekcji muzealnej; obiekt jest niekonieczny, wymienny, zastępowalny przez różnego rodzaju ekwiwalenty (kopie, multimedia) ${ }^{46}$. Drugi element, wynikający w ujęciu Kirshenblatt-Gimblett z pierwszego, to przedstawieniowy (w odróżnieniu od klasycznie wystawowego) i doświadczeniowo-nastrojowy (w odróżnieniu od informacyjnego) sposób zaprojektowania tej ekspozycji - który ma „ożywiać opowieść bez żadnych ograniczeń" ${ }^{\prime 4}$.

Przytoczona przez badaczkę definicja (opisowa) muzeum narracyjnego ${ }^{48}$, pochodząca z powstałego na początku prac nad wystawą POLIN (w latach 2000-2004) „Masterplanu”, pokazuje, jak sądzę, dość hybrydyczne rozumienie tego pojęcia. Nie jest ono jeszcze w tym dokumencie tak ustabilizowane, jak w obecnym polskim dyskursie dotyczącym muzeów; mowa o instytucjach „znanych jako muzea tematyczne lub narracyjne”, o celu stworzenia muzeum będącego "narracyjnym doświadczeniem" dla zwiedzających, muzeum "pokazującego historię", „konkretną opowieść”, i to przede wszystkim tę „zapisaną i zapamiętaną". Narracyjny charakter ma więc nie tylko efekt prac muzealników, czyli wystawa, ale i jej źródła, punkty wyjścia. Jednocześnie muzea narracyjne odróżniać ma „szerszy zasób narzędzi wystawienniczych” oraz zakres możliwości twórców i zwiedzających.

Autokomentarz Kirshenblatt-Gimblett wyróżnia odzwierciedlenie tych założeń w dość szczegółowym opisie sposobów wytwarzania opowieści zastosowanym przez twórców wystawy. Część z nich dotyczy parametrów typowych dla mówienia o narracjach: badaczka omawia więc przyjętą perspektywę narracyjną, hierarchizację nadawców narracji, podział fabuły na części, schematy fabularne, elementy świata przedstawionego, jak przede wszystkim miejsce i czas $^{49}$.

46 Ten model podejścia do obiektu jest często uważany za typowy dla muzeum narracyjnego; Monika Heinemann pisze nawet o korelacji między "zmniejszeniem znaczenia autentycznych przedmiotów i wzrostem rangi narracyjności przekazu" (Między Wschodem a Zachodem..., S. 48).

Tamże, s. 102.

Tamże, s. 107.

Podejście to współgra z zamieszczonymi w tym samym tomie refleksjami projektantki licznych wystaw, Barbary Kłaput, która przeprowadza analogię między pisaniem tekstu literackiego a tworzeniem wystawy, opierającą się na myśleniu według takich kategorii jak „świat przedstawiony, bohater, fabuła, temat, styl" (Pomiędzy Scyllą a Charybdq. Muzea narracyjne oczami projektantów, w: Muzeum i zmiana..., s. 306). 
Takie uszczegółowienie sugeruje również możliwość pojmowania muzeum narracyjnego jako stosunkowo konkretnie określonego "gatunku” współczesnego muzeum historycznego. (W tę stronę idzie cytowany wyżej Stephan Jaeger, dla którego muzeum narracyjne jest jednym z aż ośmiu typów wyróżnionych wśród XXI-wiecznych muzeów historycznych ukazujących temat II wojny światowej ${ }^{50}$ ). Do takich rezultatów doprowadziły należące do najbardziej wnikliwych na polskim gruncie badania Anny Ziębińskiej-Witek ${ }^{51}$ : autorka wyróżnia muzea narracyjne jako szczególny typ instytucji, opierając się przede wszystkim na obserwacjach dotyczących roli wystawianych w nich obiektów oraz zadań przewidzianych dla zwiedzających w kontakcie z nimi. Przeciwstawia wystawy narracyjne dwóm pozostałym kategoriom: po pierwsze, wystawom opartym przede wszystkim na rekonstrukcji i symulacji, po drugie - na interakcji i partycypacji. Nie wchodzę tu bardzo głęboko w szczegóły tej typologii ${ }^{52}$; co najistotniejsze, wystawa narracyjna, „konstruująca rozwijającą się w czasie opowieść”, stanowi typ najbardziej klasyczny, najściślej przywiązany do pojęcia prawdy historycznej. Ziębińska-Witek powołuje się tu m.in. na Weinberga i określa interesującą ją narrację jako „historiografię wizualną, czyli [próbę - przyp. M.K.] połączenia komponentów wizualnych [...], artefaktów oraz elementów tekstowych"53 w taki sposób, aby wydobywały ogólne znaczenie wystawy. Jak się wydaje, chodzi tu przede wszystkim o zastosowanie możliwie zróżnicowanych środków przestrzennych i wizualnych jako ilustracji dla ustaleń dotyczących przeszłości wynikających z badań historycznych, przy dążeniu do efektu zaangażowania, ale i spójności, zrozumiałości i obiektywności. Tak rozumiana warianty pośrednie; po drugie, sposobu wykorzystania przedmiotów stanowiących elementy wystawy, rozciągającego się między poznaniem a interakcją. Muzea narracyjne to te, które są „nastawione na przekazywanie wiedzy, jednak proces jej konstruowania przez publiczność muzealną jest wspierany przez możliwość wchodzenia w interakcję z rekwizytami. Nacisk położony jest na aktywizowanie u zwiedzających chęci do samodzielnego dociekania i przeżywania historii prezentowanych za pomocą pamiątek i eksponatów". Te dwa parametry wyznaczają osie diagramu, w który można wpisać różne typy muzeów. B. Sajduk Pokolenie Z..., s. 210-211. ująć jako wynikający z dwóch parametrów: po pierwsze, celu wystawy, który może w skrajnych A.Ziębinska-Witek Totalitaryzm..., s. 28. 
wystawa narracyjna to zjawisko odmienne i węższe niż w zrekapitulowanych poprzednio ujęciach; dość wspomnieć, że „prototypowe” Muzeum Powstania Warszawskiego w klasyfikacji Ziębińskiej-Witek byłoby muzeum łączącym dominujące cechy typu rekonstrukcyjno-symulacyjnego z elementami wystawy narracyjnej.

Reasumując - zaobserwowane odpowiedzi na postawione na wstępie pytania dotyczące pojęcia „muzeum narracyjnego" da się sprowadzić do dwóch głównych wariantów. W pierwszym z nich „narracyjność" pozostaje niedookreślona, a "muzea narracyjne” opisywane są przez zmienne konfiguracje rozmaitych cech z różnych porządków. W efekcie każde współczesne muzeum historyczne można uznać za narracyjne, ale - wbrew założeniu mojego początkowego pytania - nie pociąga to za sobą istnienia jakiejś „narracyjnej dominanty", której obserwacja dostarczałaby istotnych danych na temat tych muzeów jako zjawiska kulturowego. Człon „narracyjne” okazuje się więc do pewnego stopnia przypadkowym, nieugruntowanym elementem interesującej mnie nazwy. W drugim wariancie "muzeum narracyjne" rozumiane jest w bardziej dookreślony sposób, jako szczególny typ muzeum historycznego. Wówczas określenie to nie obejmowałoby wszystkich muzeów powszechnie klasyfikowanych jako takie, a jedynie te, dla których analiza konstrukcji wystawy ujawnia konkretne przesłanki wskazujące na prymat narracji - a operacyjne uszczegółowienie tej procedury wymagałoby dalszych, ostrożnych dociekań.

Wszystkie te próby deskrypcji i definicji można wpisać w oczywisty kontekst, jaki stanowi ogromna kariera narracji we współczesnej humanistyce - w wyniku której, jak podsumowuje Anna Łebkowska, „nie sposób nie zauważyć daleko posuniętej niejednorodności kategorii narracji [...], jej niesprowadzalności do wspólnego, jednolitego trzonu"54. Badaczka zauważa z jednej strony, że aplikowane w różnych kontekstach pojęcie narracji niekiedy ogranicza się do samej intuicji procesualności czy następstwa zdarzeń, z drugiej zaś, że poza źródłowym obszarem nauk o literaturze wyobrażenie narracji często okazuje się dość konserwatywne - chodzi o narrację klasyczną, „dobrze zrobioną",linearną, najlepiej operującą wyrazistymi schematami fabularnymi. Cytowany tekst ukazał się u zarania polskiego boomu i nie mógł uwzględniać problematyki muzealnej, widać jednak, że jej spostrzeżenia sprawdzają się również jako komentarze do rozwoju dyskursu wokół muzeum narracyjnego.

54 A. Łebkowska Narracja, w: Kulturowa teoria literatury. Główne pojęcia i problemy, red. M.P. Markowski, R. Nycz, Universitas, Kraków 2006, s. 190. 
We wszystkich powyższych uwagach nie chodzi mi oczywiście o zanegowanie istnienia narracji w konstrukcji współczesnych wystaw historycznych. Czym innym jest namysł nad narracyjnością wystaw, czym innym natomiast wyeksponowanie jej jako ich definicyjnego elementu, zwłaszcza gdy - jak się okazuje - pozostaje niedookreślone, jak przy tym wyeksponowaniu należałoby ją rozumieć. W żaden sposób nie zmniejsza to potencjału pojęcia narracji w analizie obiektów kulturowych, jakimi są wystawy muzealne; uwagi Łebkowskiej dotyczące pożytków z takich badań są niezmiennie aktualne. W tym celu proponowałabym przejście z poziomu ogólnego pytania o klasę muzeów („czym są muzea narracyjne”) na poziom bardziej szczegółowy i rozbicie problemu narracji we współczesnych muzeach na mniejsze części. Jak przypomina Łebkowska, mówiąc o narracji, trzeba rozważyć płaszczyznę opowiadania i płaszczyznę zdarzeń, czyli pamiętać zarówno o fabularności narracji, jak i o tym, że jest ona wypowiedzią, rozwijającą się w czasie oraz konstruującą podmiotowośśc5. Oczywista inspiracja literaturoznawcza podsuwa więc w tym kontekście zwłaszcza możliwość postawienia pytania o, po pierwsze, kwestię obecności narratora lub narratorów wystaw muzealnych, ich liczbę, różnice między nimi, ich hierarchię, sposoby zarządzania nią; po drugie, sytuację narracyjną: pozycję, orientację, kompetencje, personalizację tych głosów narratorskich lub jej brak, dystans narracyjny, wiarygodność i autorytatywność; po trzecie, układ fabularny, wątki, relacje między nimi; po czwarte, funkcjonalne formy podawcze narracji (rzecz jasna, nie tylko w medium tekstu) oraz występowanie odpowiedników konwencji gatunkowych.

Nie jest tu moim celem dokonanie przykładowych analiz konkretnych wystaw. Wydaje się jednak, że potencjał takiego podejścia do różnorodnych przypadków muzealnych jest widoczny już na wstępnym etapie ich badania. Dla przykładu, samo rozważenie pytania o liczbę i hierarchię narratorów otwiera możliwość nietrywialnego opisu znanej struktury wystawy stałej w Muzeum POLIN - z jej setkami cytatów z różnych rzeczywistych wypowiedzi pochodzących z kolejnych epok, wyeksponowanymi wizualnie na ścianach kolejnych galerii, oraz dyskretniejszą obecnością obiektywizującego komentarza. Mamy więc tu szereg dość mocno spersonalizowanych narratorów i narratorek osadzonych w świecie przedstawionym, którzy zabierają głos tylko na chwilę, aby zaraz potem zniknąć. Zestawienia konkretnych obserwacji wymagałaby natomiast analiza zdepersonalizowanego narratora, który np. dopowiada charakterystykę „pomniejszych" narratorów, podsumowuje 
czy zbiera informacje - jak pisze Kirshenblatt-Gimblett, byłby to ekspercki "głos muzeum"56. Analizie tej należałoby poddać wypowiedzi posługujące się różnymi środkami: tekst umieszczony na mniejszych planszach na wystawie (w tym na tych wprowadzających do kolejnych galerii, zawierających przeważnie zwrot do adresata - zwiedzającego), podpisy ekspozytorów, ale także głos lektora kolejnych instalacji audiowizualnych (bardziej i mniej dominujący różne sale wystawy); to oczywiście dopiero łatwy początek, niewychodzący poza narrację zasadniczo językową. Już tutaj pojawiają się jednak pytania, czy mamy do czynienia z jednym, niezmiennym "głosem muzeum", z jego przemianami czy z wielością narratorów. Hierarchizacja instancji narracyjnych wystawy w POLIN będzie więc zawiłym zagadnieniem, tym bardziej że ich relacje mogą okazać się dynamiczne. Nie trzeba dodawać, że jej prześledzenie będzie ważne dla analizy kompetencji, wiarygodności i autorytatywności narratorów.

Tego typu dociekania mogą okazać się płodne nie tylko w przypadku wystaw, w obrębie których pojawiają się wyraźnie spersonalizowani narratorzy (jak w Muzeum Powstań Śląskich w Świętochłowicach, gdzie projekcyjna postać narratora prowadzi zwiedzających jak przewodnik przez kolejne sale, przy czym część jego cech pozostaje niezmienna - kreuje go jeden aktor, Zbigniew Stryj - a część przekształca się, np. w sugestii, że mamy do czynienia z postacią osadzoną w okresie i miejscu, o którym opowiada w danej sali), choć to w ich stronę mogą iść pierwsze skojarzenia. Również w mniej barwnych przypadkach ustalenie składowych obiektywizującego „głosu muzeum", zinterpretowanie, czy podlega on przekształceniom, np. czy zmienia pozycję i dystans, może być istotne, by udzielić konkretnej, nieopartej tylko na ogólnym odbiorczym wrażeniu, odpowiedzi na pytania dotyczące polityki pamięci danego muzeum. Aby więc $\mathrm{z}$ badania narracji na wystawach muzealnych płynęły poznawcze pożytki, nie jest konieczne rozstrzyganie generalnych pytań o przynależność do klasy „muzeów narracyjnych” i jej definicję.

\section{Muzeum doświadczeniowe: dominanta?}

Nie sposób jednak oddalić pozostającego cały czas w tle pytania, czy to rzeczywiście narracyjność jest tym, co określa współczesne muzea historyczne zarówno ich konstrukcję, jak i postrzeganie przez znawców i zwiedzających. Z pewnością można i trzeba analizować muzealne narracje. Kategorię narracji 
można jednak z powodzeniem przyłożyć do mnóstwa zjawisk współczesnej kultury - dla przykładu, do widowisk telewizyjnych czy ulicznych demonstracji. Czy „nowe muzea historyczne” są w porównaniu z nimi „szczególnie” narracyjne, czy narracyjność określa je trafnie i w pełni, co uzasadniałoby funkcjonującą nazwę? Przegląd powyższych stanowisk nie dostarczył ostatecznych i przekonujących argumentów w tej sprawie.

Mimo omówionej wyżej pozycji pojęcia „muzeum narracyjne” pojawiają się również inne terminy, które miałyby określać wszystkie lub niektóre z tych placówek - w tym choćby muzeum fabularne, informacyjne, emocjonalne, performatywne ${ }^{57}$. Poszukiwanie takiego określenia wydaje mi się wartościowe z podstawowego powodu. Nawet powierzchowna analiza recepcji nowych polskich muzeów historycznych pokazuje, że są one postrzegane i funkcjonują jako zjawiska mające ze sobą wiele wspólnego, pochodzące zasadniczo z jednego porządku, jako pewien nowy rodzaj przestrzeni do aktywności kulturowej (a przede wszystkim pamięciowej), wymagający wypracowania pewnych podobnych kompetencji. Oczywiście to bardzo skromny punkt wyjścia: nic nie stoi na przeszkodzie, aby odpowiedzialny za to był rodzaj podobieństwa rodzinnego, więc istnienie jakiejś wspólnej im wszystkim cechy, mającej zarazem charakter wyróżnika, nie jest pewne. Dlatego nie aspirując w żaden sposób do proklamowania obowiązującego terminu, spróbuję na koniec wskazać, dlaczego i w jaki sposób rozwiązania można poszukać w innym pojęciu-kluczu współczesnej humanistyki: doświadczeniu.

Oczywiście badania nad muzeami i doświadczeniem mają swoją obszerną bibliografię, poczynając od klasycznego już tzw. interaktywnego modelu doświadczenia muzealnego autorstwa Johna Falka i Lynn Dierking ${ }^{58}$; nie będę jej tu jednak szerzej omawiać, ograniczając się do wspomnienia o pracach dwóch badaczek, których uwagi dotyczące narracyjności były już wyżej cytowane. „Doświadczenie muzealne”, ujmowane chętnie przez badaczkę w kategoriach teatralności, przestrzeni i ruchu, wydaje się jednym z kluczowych

57 Por. np. D. Kosiński Wystawa jako doświadczenie. Performatywne aspekty muzeum, w: I Kongres Muzealników Polskich, s. 193-201; P. Kosiewski Muzeum i narracja, s. 63; I. Skórzyńska Muzeum historyczne: teatr - widowisko, aktor - świadek, w: Historia Polski od-nowa..., s. 93. Muzealny "zwrot performatywny" krytycznie analizuje A. Ziębińska-Witek (Zwrot performatywny..., zwł. s. 304-307).

58 Por. np. J.H. Falk, L.D. Dierking The Museum Experience, Howells House, Washington 1992; Learning from Museums. Visitor Experiences and the Making of Meaning, Altamira Press, Lanham 2000. 
pojęć w znanej koncepcji muzeum-katalizatora Kirshenblatt-Gimblett ${ }^{59}$. Charakteryzuje tu ona zmianę paradygmatyczną we współczesnym muzealnictwie oraz kreśli pełną nadziei, nawet jeśli utopijną, wizję muzeum jako medium czerpiącego ze swojej przeszłości, aby inspirować do kolaboratywnych, włączających, nastawionych na przyszłość wystawienniczych przedsięwzięć. Doświadczenie muzealne staje się katalizatorem wielokierunkowych, twórczych działań. Ziębińska-Witek, instruktywnie referując transformacje współczesnego doświadczenia muzealnego i dążąc do ujęcia muzeum jako „przestrzeni doświadczeń”, również szczególnie uwzględnia paradygmat partycypacyjny. Prowadzi ją to do wniosku, że „to, co wydaje się kluczowe we współczesnym doświadczeniu muzealnym, to [...] spektakl, performatywność/interaktywność i «wydarzeniowość» wystawy umieszczonej w przestrzeni ekspozycyjnej oferującej wielość doznań"60.

Gdy próbuje się uchwycić czynnik lub czynniki podstawowej „wspólnej jakości" nowych muzeów historycznych, nie wystarczy sięgnąć do podstawowych wrażeń zwiedzających, zachowanych w wybiórczych świadectwach recepcji (szczególnie ze względu na fragmentaryczność dotychczasowych badań w tej sprawie). Kluczowe jest to, czy sposób konstrukcji muzeów (przede wszystkim wystaw) przewiduje jakiś podstawowy zbieżny scenariusz odbioru. Wydaje się, że posługując się bardzo różnymi środkami, osiągają one efekt, jakim jest właśnie wystawienie podmiotu na intensywne d o ś w i a d c z e n i e. Rzecz jasna, taki hipotetyczny wyróżnik nie może służyć do tego, aby jednoznacznie odróżnić oddziaływanie muzeów od licznych innych doświadczeniowych aparatów nowoczesności i współczesności. Moim celem jest jednak przede wszystkim wskazanie „wspólnego mianownika” różnorodnych muzealnych konstrukcji. Wyróżniające wydają się więc skala i siła udzielających się podmiotom doświadczeń.

Intensywność, którą mam tu na myśli, nie daje się sprowadzić do monumentalności, interakcyjności, multimedialności, narracyjności, polityczności, teatralności, różnorodności czy wielozmysłowości współczesnych wystaw, ale niejako nadbudowuje się nad nimi; jej podstawą mogą stać się rozmaite zestawy bodźców. Powtarza się jednak sytuacja, w której muzeum nakierowane jest na wytwarzanie - sięgnę tu do bardzo codziennego języka - efektu

59 B. Kirshenblatt-Gimblett Muzeum jako katalizator, przeł. D. Żukowski, w: Laboratorium muzeum. Tożsamość, red. A. Banaś, W. Chodacz, A. Janus, Dom Spotkań z Historią, Warszawa 2018, s. 36-67.

60 A. Ziębińska-Witek Historia w muzeach..., s. 50. 
bycia pod wrażeni e m. Przestrzenna metafora pojęciowa, którą podpowiada polszczyzna, wydaje się bardzo trafna w opisie sytuacji zwiedzających wobec ich własnych muzealnych doświadczeń.

Intensywność doświadczenia, o które chodzi, różni się od intensywnego doświadczenia np. lektury czy kontemplacji: nie jest osiągana przez celowy (często skupiony i stopniowy) wysiłek podmiotu, natomiast staje się punktem wyjścia skłaniającym go do dalszych wysiłków, przede wszystkim porządkujących i interpretacyjnych. Muzea działają najpierw przez poruszenie, wytrącenie ze zwyczajnej równowagi; chwilowo zredukowane zostają doświadczenia i nastawienia pozamuzealne, sytuacja muzealna przejmuje większość lub całość percepcji i uwagi ${ }^{61}$. Nie musi tu chodzić o paraliżujące obezwładnienie - równie dobrze w grę wchodzi zaintrygowanie, zafrapowanie, uznanie dla muzealnej koncepcji czy różne rodzaje wzruszeń. Regułą jest jednak scenariusz odbiorczy, w którym zwiedzający doświadczają przestrzeni intensywnej, kompleksowej, wciągającej, a nawet ekscytującej, a jednocześnie nie do końca czytelnej, obiecującej dalsze wrażenia, domagającej się eksploracji, ogarnięcia i zrozumienia. Zarządzanie dystrybucją własnej uwagi i sposobem doświadczania muzeum staje się odtąd głównym zadaniem zwiedzających. Muszą oni - zapewne ze zmienną koncentracją i powodzeniem - wypracowywać sposoby orientowania się na wystawie, wybierać, czemu poświęcą uwagę, rozpoznawać konkretne obiekty czy rodzaje przestrzeni, dostosowywać do nich sposób percepcji, odnosić elementy do siebie, dostrzegać tematy i wątki przewodnie, odczytywać suflowane oceny i postawy, poddawać się lub opierać emocjom. Jednocześnie zaś w związku z tym wszystkim ostatecznie doświadczają także siebie jako zwiedzających.

Sądzę, że wskazanie na intensywne doświadczenie jako na dominantę sposobu konstrukcji współczesnych muzeów historycznych może obsłużyć przynajmniej większość dotyczących ich intuicji, które analizowałam w tym tekście. Nie może jednak funkcjonować jako rozstrzygające kryterium selekcyjne: trudno wyobrazić sobie „test intensywności” doświadczenia muzealnego i próg decydujący o tym, które muzea nie mogą zostać zaliczone do tej grupy, szczególnie ze względu na różnorodność wchodzących w grę doświadczeń i sposobów wystawiania na nie zwiedzających. Świadomie

61 Por. uwagi Iwony Kurz o muzeosensorium, w artykule Narcyz w muzeum. Przygoda ponowoczesna, w tym numerze "Tekstów Drugich". Rzecz jasna, "bycie pod wrażeniem”, o którym piszę, nie jest stabilną jakością nieulegającą zmianom podczas zwiedzania wystawy, a fluktuacje, jakim ulega, są ważną częścią muzealnego doświadczenia. 
ograniczam się tu do rozważań nad muzeami historycznymi i wyprowadzam wnioski z tego, jakie muzea powstały w ramach polskiego boomu: dlatego piszę o dominancie raczej niż o istocie, zasadzie czy definicji. Sądzę jednak, że przydatność tej obserwacji leży w sferze interpretacji działania konkretnych wystaw i porównywania ich między sobą. Intensywne doświadczenia muzealne stają się treningiem praktyk pamięciowych, będącym istotą tożsamościowego, społecznego i politycznego oddziaływania muzeów historycznych.

\section{Abstract}

\section{Maria Kobielska}

JAGIELLONIAN UNIVERSITY (CRACOW)

Narrative Museum - Experiential Museum: Remarks on the Terminology

Classifying the new historical museums that have been established in Poland over the last fifteen years the most widely used term is"narrative museum" [muzeum narracyjne]. Kobielska analyses concrete occurrences of this label in the discourse of museum studies; she categorises the intuitions implied in them and describes the origin of the term. This leads her to argue that its operability is limited and that solidly founded analyses of concrete museum narratives are needed. Examining alternative possibilities to tackle the problem she proposes the concept of (intensive) experience as the dominant factor in the way that historical museums are constructed. Expressing this in a nutshell, these museums could be called "experiential museums".

\section{Keywords}

narrative museum, experiential museum, Polish museum boom, narrative, storytelling, experience of museum 